\title{
Biochemical changes in lipid and carbohydrate metabolism in obese diabetic male albino rats
}

\author{
Mostafa M. Osfor ${ }^{1}$, Osama Kensarah ${ }^{1}$, Firas Azzeh ${ }^{1, *}$, Mohammad A. Elmadbouly ${ }^{1}$, \\ Mona El-Qutry ${ }^{2}$
}

${ }^{1}$ Clinical Nutrition Department, Applied Medical Sciences College, Umm Al-Qura University, Makkah, Saudi Arabia

${ }^{2}$ Nutrition and Food science, Home Economic Collage, Ain Shame University, Cairo, Egypt

\section{Email address:}

fsazzeh@uqu.edu.sa (F. Azzeh)

\section{To cite this article:}

Mostafa M. Osfor, Osama Kensarah, Firas Azzeh, Mohammed El-Madbouly, Mona El-Qutry. Biochemical Changes in LIPID and Carbohydrate Metabolism in Obese Diabetic Male Albino Rats. International Journal of Nutrition and Food Sciences. Vol. 2, No. 2, 2013, pp. 24-30. doi: 10.11648/j.ijnfs.20130202.11

\begin{abstract}
The effect of high fat diet on lipid and carbohydrate metabolic changes was studied in mature male albino rats. The animals were rendered obese by feeding a high fat diet for 60 days. Half of obese rats were become diabetic by injecting with a reduced dose of alloxan; to produce a non insulin dependent diabetes mellitus state. These obese models of non diabetic and diabetic rats were compared with normal male rats kept on a basal diet for 60 days. The fat fed rats beside gaining weight showed a significant rise in their hepatic lipid contents and observed an insulin resistant state. Lipid profile of the omental adipose tissue exhibited a significantly higher total lipid content, but lower total cholesterol, triglycerides and phospholipids contents in both obese (non diabetic and diabetic) as compared with the normal rats. On the other hand, the brown adipose tissue showed a reduced fat catabolism with a significant rise in its phospholipid contents. Correlation between plasma atherogenic index and plasma fatty acids pattern showed that in the obese diabetic rats atherogenic index was positively correlated with total polyunsaturated fatty acids, while significantly negative correlation with total saturated fatty acids. This work showed that high fat substrates have been got remarkable impacts on rats body weight and metabolism.
\end{abstract}

Keywords: Obesity, Diabetes, Male Albino Rats

\section{Introduction}

Obesity is a state of abnormal accumulation of neutral fat in the storage depot of the body. It is ultimately the consequence of ingesting more calories than those needed. Obesity is the most common disorder of metabolism and is also one of the oldest stresses and dietary habits. The predisposing factors to obesity may be physical, nutritional, pharmacological, maturational, socioeconomic and environmental factors. Obesity has been identified as an important risk factor in the development of atherosclerosis and coronary heart disease [1]. Although, there are recognized hereditary and hormonal factors contributing excess weight, overeating is without doubt one of the causative factors in obesity. It is associated with four major factors for atherosclerosis, hypertension, diabetes, hypercholesterolemia and hypertriglyceriemia. Therefore, it is not surprising that obese subject have more susceptibility to sudden death [2]. Storlien and his team demonstrated that feeding rats a high fat $\operatorname{diet}(59 \%$ of energy) for 24 days induced whole body insu- lin resistance and inhibited insulin stimulated glucose utilization by the liver, skeletal muscles as well as brown and white adipose tissues [3]. Also, they found that the fat diet induced insulin resistance in rats can be prevented by the inclusion of n-3 polyunsaturated fatty acids in the diet [3]. Pelinkanova et al reported that insulin sensitivity has been correlated with the ratio of n- 6 polyunsaturated to the ratio of saturated fatty acids in human serum [4].

The analysis of fatty acids composition in blood and tissue lipids has lately gained renewed interest to study the pathogenesis of metabolic diseases. Fatty acids of the adipose tissue are a major supply for the plasma fatty acids pool [5]. The liver utilizes plasma fatty acids in building up the different plasma lipids and lipoprotein [6], that is implicated in the different metabolic reactions in health and disease [2].

The present study is an experimental attempt carried out on male albino rats to find out how dietary obesity affects carbohydrate, lipid and lipoprotein metabolism and their correlation with the different fasting plasma fatty acids, which reflect the endogenous composition of adipose tis- 
sues.

\section{Materials and Methods}

\subsection{Experimental Animal and Housing}

Thirty adult male albino rats were randomly taken from the flock bred in the animal house laboratory of the National Research Center, Dokki, giza, Egypt; with average body weight 120 - 130 gram. The animals were kept in transparent fiber-glass cages covered by stainless steel mesh provided with suitable places for keeping food and suckling bottle for watering.

\subsection{Diet and Watering}

The basal diet was formulated to meet the rat's nutrient requirements as mentioned in Osfor work [7]. Basal and fattening diets with their composition are shown in Table (1). Water and feed were available all the time during the experimental period.

Table 1. Composition of the Basal and experimental Diet.

\begin{tabular}{lll}
\hline Ingredient & $\begin{array}{l}\text { Basal } \\
\text { et } \%\end{array}$ & $\begin{array}{c}\text { Di-Experimental Diet } \\
(\mathbf{6 0} \% \mathbf{f a t})\end{array}$ \\
\hline Wheat Flour & 77 & 16.07 \\
Meat Meal & 6.0 & 20 \\
Animal Fat & 3.5 & 57.93 \\
Wheat Bran & 10 & 3.0 \\
Lysine & 0.6 & 0.1 \\
Methionine & 0.4 & 0.4 \\
Di-calciumphosphate & 1.0 & 1.0 \\
Sodium chloride & 0.5 & 0.5 \\
Vit. \& Min. Mix & 1.0 & 1.0 \\
Calculated Nutrient Composition & & \\
Crud protein & 14.01 & 12.67 \\
Energy (ME / KG) & 3296.6 & 6239.23 \\
Ether Extract & 5.27 & 60.02 \\
Crude fiber & 3.83 & 3.75 \\
Ash & 3.06 & 5.77 \\
Lysine & 1.09 & 0.81 \\
Methionine & 0.61 & 0.58 \\
Calcium & 0.91 & 2.06 \\
Phosphorus & 0.64 & 1.12 \\
\hline
\end{tabular}

\subsection{Experimental Design}

For this study, 30 mature male albino rats were divided into 3 groups used as following:

Group 1: fed the basal diet only and served as control group.

Group 2: fed high fat diet (60\% fat) and served as obese group.

Group 3: fed high fat diet (60\% fat) and induced diabetic by Alloxan injection and served as obese and diabetic group. days.

Feeding treatments for all groups have been lasted for 60

\subsection{Preparation of Diabetic Rats}

Rats were injected sub/cutaneously with $120 \mathrm{mg} / \mathrm{kg}$ body weight Alloxan, after 24 hours fasting.

\subsection{Characteristics Investigated}

Body weight, Food consumption, Blood analysis and final investigations all were measured in this study as following:

Body weight was recorded individually at week interval before offering the diet. Food consumption was calculated daily, as the differences between the amount of offered and residual food. Regarding blood analysis, at the end of the experimental period, about $2 \mathrm{ml}$ blood were collected from the retro-bulbar venous plexus, through heparinzed capillary tubes; after overnight fasting. The plasma was separated in polyethylene tubes after centrifugation for 10 minutes at $3000 \mathrm{rpm}$. Blood glucose was estimated immediately, and the rest of plasma was kept frozen for the subsequent blood analysis. Finally, the animals were anaesthetized and decapitated. The liver, omintal and brown adipose tissues were carefully dissected out and weighed. The obtained tissues were homogenized in a glass homogenizer, and preserved frozen for determination of their fat.

\subsection{Methods and Biochemical Analysis}

The total lipids in liver or adipose tissue were extracted with chloroform - methanol (2:1) according to the method of Folch and Stanley [8]. Aliquots of the extract were used for estimation of triglycerides, phospholipids and total cholesterol. Blood glucose was determined according to the enzymatic method of Siest et al [9]. Plasma Insulin was estimated by the radioimmunoassay method of Yalow and Bauman [10]. The plasma total lipids were determined by the colorimetric method with sulfophosphovanilic mixture by Schmit and Dervon [11]. The plasma lipids were prepared first by Dole's method [12], then methylated, then quantitated by means of computerized Gas Liquid Chromatography (GLC); Model varian 3700. The fatty acids were identified by comparing their retention times with those of standard mixture, the content of individual fatty acids in plasma was expressed as a percentage of the total fatty acids identified. Triglycerides in both plasma and tissue extract were determined by glycerol phosphate oxidase method by Fossati and Prencipe [13]. Phospholipids were estimated in both plasma and tissue extract according to the procedure of King and Woolton [14]. Total cholesterol was determined in plasma according to the enzymatic method of Allain et al [15], and estimated in tissues according to the method of Ratliff and Hall [16]. Plasma High density lipoprotein (HDL-C) was measured according to the method of Lopez-Virella et al [17], while plasma low-denisty and very low density lipoprotein cholesterol (LDL-C and VLDL-C) were estimated according to Glatter equation [18].

\subsection{Statistical Analysis}

All results were expressed as means \pm S.E. Data were analyzed in SPSS (Statistical Package for Social Sciences) software version 17 using student's t- test. Qualitative variables expressed as percentage were compared in different groups. Relationships between variables were analyzed using the simple correlation coefficient of Armitage [19]. 


\section{Results}

As shown in Table 2, obese rats exerted significantly $(\mathrm{P}<$ $0.05)$ higher in body weight, fasting blood glucose and plasma insulin than control rats. Furthermore, obese diabetic rats showed significantly $(\mathrm{P}<0.01)$ higher values of previous parameters than other groups.

Table 2. Body weight (g), Fasting blood glucose ( $\mathrm{mg} / \mathrm{dl})$ and plasma insulin $(\mu \mathrm{Iu} / \mathrm{ml})$ of studied groups after 60 days.

\begin{tabular}{llll}
\hline Group & Body weight & Blood Glucose & Insulin \\
\hline Group I & $155.9 \pm 3.59$ & $96.350 \pm 5.77$ & $7.220 \pm 0.42$ \\
Group II & $292.4 * \pm 5.83$ & $107.57 \pm 5.92 *$ & $11.63 \pm 0.66^{*}$ \\
Group III & $336.9 * * \pm 8.780$ & $304.21 \pm 5.73^{* *}$ & $24.05 \pm 1.25 * *$ \\
\hline
\end{tabular}

Data are expressed as Means \pm S.E. $*<0.05:$ Significant. $* *<0.01:$ High significant

From Table 3, it was shown that the mean values of hepatic total lipids, total cholesterol, and triglycerides concentrations were significantly elevated $(\mathrm{P}<0.01)$ in obese non diabetic and obese diabetic $(\mathrm{P}<0.01)$ as compared with the control rats, while liver phospholipids were not changed between groups. Plasma lipids, with regard to total lipids, total cholesterol, triglycerides and phospholipids, were significantly increased in both obese non-diabetic and diabetic rats when compared with the control rats.

Table 3. Liver and Plasma lipids concentrations in obese diabetic and non diabetic rats.

\begin{tabular}{|c|c|c|c|c|c|c|c|c|}
\hline & Liver lipid & & & & Plasma Lipid & & & \\
\hline Group & $\begin{array}{l}\text { T. Lipid } \\
\mathrm{Mg} / \mathrm{g}\end{array}$ & $\begin{array}{l}\text { Tri-Glyc } \\
\text { Mg/g }\end{array}$ & $\begin{array}{l}\text { Phos-Lipid } \\
\text { Mg /g }\end{array}$ & $\begin{array}{l}\text { T. Choles } \\
\mathrm{Mg} / \mathrm{dl}\end{array}$ & $\begin{array}{l}\text { T. Lipid } \\
\mathrm{Mg} / \mathrm{g}\end{array}$ & $\begin{array}{l}\text { Tri- Glyc } \\
\mathrm{Mg} / \mathrm{g}\end{array}$ & $\begin{array}{l}\text { Phos-lipid } \\
\text { Mg /g }\end{array}$ & $\begin{array}{l}\text { T.Choles } \\
\text { Mg /dl }\end{array}$ \\
\hline Group I & $43.99 \pm 2.59$ & $11.02 \pm 0.83$ & $22.43 \pm 0.55$ & $2.81 \pm 0.10$ & $392.9 \pm 6.7$ & $42.4 \pm 3.44$ & $117.3 \pm 6.2$ & $67.2 \pm 4.52$ \\
\hline Group II & $73.92 \pm 4.67 * *$ & $38.46 \pm 2.70 * *$ & $24.13 \pm 0.74$ & $4.45 \pm 0.10 * *$ & $589.5 \pm 11.2 * *$ & $90.79 \pm 5.75^{* *}$ & $242.4 \pm 7.8 * *$ & $99.3 \pm 3.53 * *$ \\
\hline Group III & $81.88 \pm 4.60 * *$ & $43.72 \pm 2.87 * *$ & $24.24 \pm 0.90$ & $6.69 \pm 0.17 * *$ & $877.4 \pm 11.7 * *$ & $221.3 \pm 5.11 * *$ & $417.2 \pm 3.1 * *$ & $124.7 \pm 4.96 * *$ \\
\hline
\end{tabular}

Data are expressed as Means \pm S.E. $*<0.05: \quad$ Significant. $* *<0.01:$ High significant

Low density and very low density lipoprotein cholesterol (LDL-C \& VLDL-C), and also atherogenic index (Table 4) were significantly increased in obese (non-diabetic and diabetic) rats. Moreover, while the high density lipoproteins
(HDL-C) and its ratio were significantly reduced in obese non diabetic $(\mathrm{P}<0.01)$ and also were significantly lower in obese diabetic $(\mathrm{P}<0.05)$ than in obese non diabetics rats $(\mathrm{P}<0.01)$.

Table 4. Plasma lipoproteins in obese diabetic and non diabetic rats.

\begin{tabular}{lllllll}
\hline Groups & $\begin{array}{l}\text { HDL-C } \\
(\mathbf{m g} / \mathbf{d l})\end{array}$ & $\begin{array}{l}\text { LDL-C } \\
(\mathbf{m g} / \mathbf{d l})\end{array}$ & $\begin{array}{l}\text { VLDL-C } \\
(\mathbf{m g} / \mathbf{d l})\end{array}$ & HDL-C/ LDL-C & HDL-C/ VLDL-C \\
& HDL-C & \\
\hline Group I & $23.26 \pm 1.18$ & $30.26 \pm 1.71$ & $8.47 \pm 0.68$ & $0.79 \pm 0.06$ & $2.84 \pm 0.21$ \\
Group II & $17.05 \pm 1.33^{* *}$ & $64.97 \pm 4.19^{* *}$ & $18.16 \pm 1.15^{* *}$ & $0.27 \pm 0.02^{* *}$ & $0.97 \pm 0.11^{* *}$ & $5.069 \pm 0.452^{* *}$ \\
Group III & $10.18 \pm 1.01^{* *}$ & $72.63 \pm 4.06^{* *}$ & $44.26 \pm 1.02^{* *}$ & $0.15 \pm 0.02^{* *}$ & $0.23 \pm 0.02^{* *}$ & $12.67 \pm 1.790^{* *}$ \\
\hline
\end{tabular}

Data are expressed as Means \pm S.E. $*<0.05:$ Significant. $* *<0.01:$ High significant

The omental adipose tissue (from Table 5) showed a higher content of total lipids in obese (non diabetic \& diabetic) rats $(\mathrm{P}<0.05)$, meanwhile, the mean values of total cholesterol, triglycerides an phospholipids were significantly lower in obese non diabetic and also in obese diabetic rats. The results also showed that the triglycerides concentration was significantly lower $(\mathrm{P}<0.01)$ in obese diabetic versus obese non diabetic rats. Brown adipose tissue of obese non diabetic rats showed a significant rise $(\mathrm{P}<0.05)$ in total lipids and phospholipids contents; while the mean value of total cholesterol was significantly lower $(\mathrm{P}<0.05)$ in obese non diabetic \& obese diabetic rats $(\mathrm{P}<0.01)$ when compared with the control rats.

Table 5. Lipid contents of omental and Brown adipose tissue in obese diabetic and non diabetic rats.

\begin{tabular}{|c|c|c|c|c|c|c|c|c|}
\hline \multirow[b]{2}{*}{ Groups } & \multicolumn{4}{|c|}{ Omental adipose tissue } & \multicolumn{4}{|c|}{ Brown adipose tissue } \\
\hline & $\begin{array}{l}\text { T. Lipid } \\
(\mathrm{mg} / \mathrm{g})\end{array}$ & $\begin{array}{l}\text { T. Chol } \\
\text { (mg/g) }\end{array}$ & $\begin{array}{l}\text { Triglyc } \\
\text { (mg/g) }\end{array}$ & $\begin{array}{l}\text { Pho.Lipid } \\
\text { (mg/g) }\end{array}$ & $\begin{array}{l}\text { T. Lipid } \\
\text { (mg/g) }\end{array}$ & $\begin{array}{l}\text { T. Chol. } \\
\text { (mg/g) }\end{array}$ & $\begin{array}{l}\text { Triglyc } \\
\text { (mg/g) }\end{array}$ & $\begin{array}{l}\text { Pho.Lipid } \\
(\mathrm{mg} / \mathrm{g})\end{array}$ \\
\hline Group I & $591.1 \pm 37.2$ & $3.76 \pm 0.08$ & $319.7 \pm 9.49$ & $1.83 \pm 0.15$ & $475.0 \pm 19.8$ & $2.60 \pm 0.09$ & $246.1 \pm 5.08$ & $8.39 \pm 0.54$ \\
\hline Group II & $818.0 \pm 70.8^{*}$ & $2.56 \pm 0.36^{*}$ & $164.4 \pm 11.6^{* *}$ & $1.31 \pm 0.09 *$ & $599.7 \pm 35.2 *$ & $2.01 \pm 0.17 *$ & $234.8 \pm 8.99$ & $14.7 \pm 0.64 *$ \\
\hline Group III & $782.8 \pm 65.8^{*}$ & $1.94 \pm 0.21 * *$ & $83.12 \pm 15.8 * *$ & $1.20 \pm 0.08 *$ & $588.6 \pm 52.8^{*}$ & $1.69 \pm 0.16^{* *}$ & $262.2 \pm 11.2$ & $10.01 \pm 1.7 *$ \\
\hline
\end{tabular}


The percentage of mean value for most plasma saturated fatty acids was significantly elevated in obese non diabetic and obese diabetic when compared with control rats, as shown in Table 6, except for C15:0. While, the percentage of mean values of plasma unsaturated fatty acids were reduced considerably in obese non diabetic and remained unchanged in obese diabetic rats as compared to control group. The ratio of polyunsaturated to saturated fatty acids were significantly $(\mathrm{P}<0.05)$ decreased in obese (non diabetic and diabetic) rats. Correlations between the sum of plasma fatty acids and liver fatty acids, plasma lipids and lipoproteins are illustrated in Tables 7 and 8.

Table 6. Plasma Fatty acids profile in Obese diabetic and non diabetic rats.

\begin{tabular}{|c|c|c|c|c|c|c|c|c|c|c|c|c|c|c|c|c|}
\hline Groups & C11:0 & C12:0 & C13:0 & C14:0 & C15:0 & C16:0 & C17:0 & C18:0 & C20:0 & C22:0 & C14:1 & C16:1 & C18:1 & $\begin{array}{l}\text { C18:2 } \\
(n-6)\end{array}$ & $\begin{array}{l}\text { C18:3 } \\
(n-6)\end{array}$ & $\begin{array}{l}\text { P:S } \\
\text { ratio }\end{array}$ \\
\hline Group I & $\begin{array}{l}0.674 \pm \\
0.081\end{array}$ & $\begin{array}{l}1.193 \pm \\
0.045\end{array}$ & $\begin{array}{l}1.668 \pm \\
0.062\end{array}$ & $\begin{array}{l}1.314 \pm \\
0.032\end{array}$ & $\begin{array}{l}1.203 \pm \\
0.061\end{array}$ & $\begin{array}{l}1.746 \pm \\
0.076\end{array}$ & $\begin{array}{l}2.047 \pm \\
0.063\end{array}$ & $\begin{array}{l}2.378 \pm \\
0.036\end{array}$ & $\begin{array}{l}2.247 \pm \\
0.088\end{array}$ & $\begin{array}{l}2.116 \pm \\
0.067\end{array}$ & $\begin{array}{l}1.042 \pm \\
0.063\end{array}$ & $\begin{array}{l}1.096 \pm \\
0.060\end{array}$ & $\begin{array}{l}2.955 \pm \\
0.044\end{array}$ & $\begin{array}{l}3.213 \pm \\
0.040\end{array}$ & $\begin{array}{l}3.230 \pm \\
0.061\end{array}$ & $\begin{array}{l}0.874 \pm \\
0.045\end{array}$ \\
\hline Group II & $\begin{array}{l}1.807 \pm \\
0.037^{* *}\end{array}$ & $\begin{array}{l}2022 \pm \\
0.062 * *\end{array}$ & $\begin{array}{l}2.049 \pm \\
0.062^{* *}\end{array}$ & $\begin{array}{l}1.906 \pm \\
0.098^{* *}\end{array}$ & $\begin{array}{l}1.270 \pm \\
0.142\end{array}$ & $\begin{array}{l}2.147 \pm \\
0.070^{*}\end{array}$ & $\begin{array}{l}1.623 \pm \\
0.061^{* *}\end{array}$ & $\begin{array}{l}2.004 \pm \\
0.069^{* *}\end{array}$ & $\begin{array}{l}2.493 \pm \\
0.073 * *\end{array}$ & $\begin{array}{l}2.524 \pm \\
* 0.077^{* *}\end{array}$ & $\begin{array}{l}1.812 \pm \\
* 0.033^{* *}\end{array}$ & $\begin{array}{c}1.879 \pm \\
* 0.064^{* *}\end{array}$ & $\begin{array}{c}2.732 \pm \\
* 0.070^{*}\end{array}$ & $\begin{array}{l}2.420 \pm \\
0.073^{* *}\end{array}$ & $\begin{array}{l}3.041 \pm \\
* 0.064 *\end{array}$ & $\begin{array}{l}0.424 \pm 0 \\
.019^{* *}\end{array}$ \\
\hline Group III & $\begin{array}{l}1.381 \pm \\
0.046^{* *}\end{array}$ & $\begin{array}{l}1.382 \\
0.101\end{array}$ & $\begin{array}{l}1.340 \pm \\
0.042^{*}\end{array}$ & $\begin{array}{l}1.394 \pm \\
0.097\end{array}$ & $\begin{array}{l}1.125 \pm \\
0.123\end{array}$ & $\begin{array}{l}2.255 \pm \\
0.055^{* *}\end{array}$ & $\begin{array}{l}2.503 \pm \\
0.037^{* * *}\end{array}$ & $\begin{array}{l}2.777 \pm \\
0.025^{* *}\end{array}$ & $\begin{array}{l}2.930 \pm \\
0.042^{* *}\end{array}$ & $\begin{array}{c}2.822 \pm \\
0.046^{* *}\end{array}$ & $\begin{array}{r}2.398 \pm \\
* 0.028^{* *}\end{array}$ & $\begin{array}{r}2.348 \pm \\
* 0.061^{* *}\end{array}$ & $\begin{array}{rl} & 2.969 \pm \\
* & 0.054\end{array}$ & $\begin{array}{l}3.168 \pm \\
0.052\end{array}$ & $\begin{array}{l}3.256 \pm \\
0.043\end{array}$ & $\begin{array}{l}0.548 \pm \\
0.024 *\end{array}$ \\
\hline
\end{tabular}

$P: S$ ratio $=$ Ratio between sum of polyunsaturated and sum of saturated fatty acids. Data are expressed as Means \pm S.E. $*<0.05: \quad$ Significant. $* *<0.01:$ High significant

Table 7. Correlation coefficient of fatty acids in Plasma and liver triglycerides in Obese diabetic and non diabetic Rats.

\begin{tabular}{|c|c|c|c|c|}
\hline \multirow{2}{*}{ Fatty acids } & \multicolumn{2}{|c|}{$\begin{array}{l}\text { Triglycerides of } \\
\text { Obese non-diabetic }\end{array}$} & \multicolumn{2}{|c|}{$\begin{array}{l}\text { Triglycerides of } \\
\text { Obese diabetic rats }\end{array}$} \\
\hline & Liver & Plasma & liver & Plasma \\
\hline SFAS & -0.334 & -0.344 & $0.866^{* * *}$ & -0.397 \\
\hline C12: 0 & -0.305 & -0.403 & 0.422 & -0.080 \\
\hline C14 : 0 & $-0.741 * * *$ & -0.269 & $0.654 * *$ & -0.372 \\
\hline C16: 0 & 0.294 & 0.344 & -0.314 & $0.463 *$ \\
\hline C18: 0 & $-0.575^{* *}$ & -0.144 & 0.166 & -0.100 \\
\hline $\mathrm{C} 22: 0$ & 0.394 & 0.042 & 0.225 & 0.079 \\
\hline MUSFAS & $-0.560 *$ & -0.326 & $-0.784 * * *$ & 0.326 \\
\hline C14 : 1 & -0.290 & $-0.634 * *$ & $-0.771 * * *$ & $0.465^{*}$ \\
\hline C16: 1 & $0.927 * * *$ & 0.025 & 0.212 & 0.317 \\
\hline C18 : 1 & -0.021 & -0.344 & -0.401 & 0.123 \\
\hline PUSFAS & 0.229 & 0.123 & $-0.649 * *$ & 0.128 \\
\hline C18 : 2n-6 & $0.833 * * *$ & 0.007 & $-0.754 * * *$ & 0.243 \\
\hline C18 : 3n-6 & $-0.803 * * *$ & 0.108 & $-0.479 *$ & -0.021 \\
\hline $\mathrm{P}: \mathrm{S}$ ratio & 0.318 & 0.304 & $-0.808 * * *$ & 0.270 \\
\hline
\end{tabular}

SFAS : Sum of saturated fatty acids.

MUSFAS: Sum of mono-saturated fatty acids .

PUSFAS: Sum of polyunsaturated fatty acids

$P$ : S ratio: Ratio of PUSFAS : SFAS.

$*<0.05:$ Significant.

** < 0.01: High significant.

** <0.001: Very high significant 
Table 8. Correlation coefficient of plasma fatty acids with atherogenic index and lipoprotein ratio in obese diabetic and non-diabetic rats.

\begin{tabular}{|c|c|c|c|c|c|c|}
\hline \multirow[t]{2}{*}{ Fatty acids } & \multicolumn{3}{|c|}{ Obese non-diabetic rats } & \multicolumn{3}{|c|}{ Obese diabetic rats } \\
\hline & $\begin{array}{c}\text { LDL-C+VLDL / } \\
\text { HDL-C }\end{array}$ & HDL-C / LDI & L-C / VLDL-C & $\begin{array}{c}\text { LDL-C+VLDL / } \\
\text { HDL-C }\end{array}$ & HDL-C / LDI & HHDL-C / VLDL-C \\
\hline Sum of SFA & -0.253 & 0.071 & 0.342 & $-0.537^{*}$ & $0.613^{* *}$ & $0.691 * * *$ \\
\hline $\mathrm{C} 12: \mathrm{O}$ & 0.061 & 0.075 & -0.216 & $-0.707 * * *$ & $0.501^{*}$ & $0.506^{*}$ \\
\hline $\mathrm{C} 14: \mathrm{O}$ & $-0.597 * *$ & $0.582 * *$ & 0.412 & -0.222 & 0.090 & 0.415 \\
\hline $\mathrm{C} 16: \mathrm{O}$ & 0.040 & -0.280 & 0.212 & 0.064 & -0.144 & 0.032 \\
\hline $\mathrm{C} 18: \mathrm{O}$ & -0.371 & 0.203 & 0.437 & 0.037 & 0.292 & -0.066 \\
\hline $\mathrm{C} 22: \mathrm{O}$ & 0.103 & -0.344 & 0.241 & 0.239 & -0.271 & 0.033 \\
\hline Sum of MUSFA & -0.044 & 0.106 & -0.166 & 0.204 & -0.025 & -0.092 \\
\hline C14 : 1 & 0.035 & 0.055 & -0.044 & 0.325 & $-0.578 * *$ & -0.370 \\
\hline $\mathrm{C} 16: 1$ & 0.090 & -0.089 & 0.0120 & 0.077 & 0.090 & 0.161 \\
\hline C18: 1 & -0.135 & 0.013 & 0.0108 & 0.253 & 0.082 & -0.004 \\
\hline Sum of PUSFA & 0.252 & -0.009 & $-0.456^{*}$ & 0.027 & -0.190 & -0.273 \\
\hline $\mathrm{C} 18: 2$ & 0.158 & 0.255 & -0.019 & 0.146 & -0.294 & -0.373 \\
\hline $\mathrm{C} 18: 3$ & 0.373 & -0.271 & -0.311 & -0.120 & -0.051 & -0.132 \\
\hline $\mathrm{P}: \mathrm{S}$ ratio & 0.265 & -0.055 & -0.404 & $0.497 *$ & -0.406 & $-0.702 * * *$ \\
\hline
\end{tabular}

SFAS : Sum of saturated fatty acids. MUSFAS: Sum of mono-saturated fatty acids . PUSFAS: Sum of polyunsaturated fatty acids. P : S ratio: Ratio of PUSFAS : SFAS. *<0.05: Significant. ${ }^{*}<0.01$ : High significant. $* *<0.001$ : Very high significant

\section{Discussion}

High fat or high carbohydrate fed rats increased body weight probably as a consequence of changes in lipid metabolism [20,21] and storage [22]. Other workers reported changes in plasma and tissue lipids and their fatty acids composition in response to exogenous dietary variation [23]. In the present work both of fat dietary obese (non diabetic and diabetic) rats exhibited all these phenomena of elevated basal insulin, glucose levels together with rise of total lipids, and lipoprotein fractions, VLDL-C, LDL-C and decrease in HDL-C compared to the normal rats. Also, the calculated atherogenic index showed a consistent and significant rise than the control rats. All the changes observed in the obese non diabetic rats were exaggerated in the obese diabetic ones.

The fact that the increase in body weight is associated with a rise plasma VLDL-C is well known and is attributed to the increased production of TG by the liver and is associated with a reduction of VLDL-C removal [24]. Fatty liver is a common abnormality that accompanies obesity and probably induced by the over production of TG by the liver. Several obese rodents have markedly elevated rates of hepatic and/or adipose tissue Fatty acids synthesis [25].

Investigation of the different lipid fractions in the liver of the obese rat models of this study showed a significant increase in their TG and T. cholesterol contents, while the phospholipids remained unchanged in comparison with the normal rats. Constantine et al concluded that hepatic fatty changes were associated with elevated plasma lipids and lipoprotein concentration and also increased plasma insulin and glucose levels [26]. Previous results are in line with the research results. Ness-Abramof and Apovian recorded that overproduction of TG by the liver is the result of increased mobilization of free fatty acids from the adipose tissue mass in obesity [27]. Several correlations between adipose tissue and serum fatty acids and serum TG have been reported. On the other hand, De Vries et al found no correlation between adipose tissue linoleic acid content and serum TG concentration [28].

The present work included that of the lipid profile of the omental adipose tissue (OAT) and brown adipose tissue (BAT) (Table 5). It was observed that the TG and total cholesterol and phospholipids contents in OAT of the obese rats were decreased as compared with the normal rats. The low TG content of the omental fat was explained by increased lipolysis [29]. The sensitivity and responsiveness of BAT for insulin stimulated glucose transport were shown by Storlein and his team (1991) to be decreased in fat-diet fed rats. The present data showed that the BAT in fat-diet induced obesity exhibited a significant reduction in its total cholesterol content and significant rise in its total lipids and phospholipids contents. In genetically obese rats, the antilipolytic and metabolic effects of insulin on BAT are impaired as a result of insulin resistance [25]. Also, the calorigenic effect of norepinephrine is reduced [30].

In fat fed rats of this work, the resulting insulin resistance could play a pivotal role in the metabolic consequences obtained in the metabolism of BAT. These facts explain the reduces in phospholipid catabolism of the BAT of obese rats, perhaps as a result of reduced thermogenic effect of the catecholamine hormone (noreepinephrine), which may be similar to what happens in obese rats of genetic origin [31]. The increased lipolysis of adipose tissue fat explains the observed rise in plasma fatty acids which also lend support to the fact that plasma fatty acids are mostly of endogenous origin [31].

In the present model of dietary obese rats, the plasma fatty acid profile recorded a substantial rise in saturated fatty acids in comparison with the normal rats. This substrate supply of fatty acids interferes with glucose utilization [2]. 
Accordingly, insulin secretion is stimulated which tends to changes the fatty acids levels [32]. The mass of adipose tissue overcomes this regulatory effect. Thus hyperinsulinemia and insulin resistance are early metabolic changes in obesity [33] and the increased adipose tissue mass perpetuates the increased supply of fatty acids and insulin resistance. The increased flux of fatty acids to the liver consequent to the reduced antilipolytic effect of insulin is responsible for VLDL-C production [34]. In fact both basal and glucose stimulated insulin concentration were elevated in rats fed high fat diet [35].

Correlation studies between the percentages of plasma fatty acids and liver TG in obese (non diabetic \& diabetic) rats showed that the decrease in P:S ratio was associated with enhanced hepatic triglycerides synthesis in obese diabetic rats which was not detrimental in the obese non diabetic rats. Thus the P:S ratio was weakly positively correlated with hepatic TG in the obese non diabetic rats. The hepatic synthesis of TG in the form of VLDL-C was reflected on the plasma lipids in the obese non diabetic rats. In the last group of rats, correlation of plasma fatty acids with plasma TG showed the same correlation as those with liver TG with the exceptions of $\mathrm{C} 16: 1$ and $\mathrm{C} 18: 3$. In the obese diabetic rats on the other hand, such correlation were not similar, perhaps this was because diabetic livers showed fatty changes as a result of TG accumulation in the liver [36].

The correlation between the plasma fatty acids and the various lipoprotein ratios, atherogenic index (VLDL-C + LDL-C / HDL-C) found that in obese non diabetic rats, the atherogenic index (where HDL-C is the denominator) was inversely correlated with the percentage of the individual saturated fatty acids especially C14:0, but weakly negatively correlated with the percentage of the sum of saturated fatty acids. On the other hand, with the unsaturated fatty acids, this index was weakly positively correlated with the percentage of the polyunsaturated fatty acid $\mathrm{C} 18: 3$ and the sum of the polyunsaturated fatty acids and $\mathrm{P}: \mathrm{S}$ ratio. The correlation with the HDL-C/LDL-C and HDL-C/VLDL-C (where HDL-C is the nominator), were more or less the reverse to those of the atherogenic index where they were weakly positively correlated with the saturated fatty acid C14:0 and the sum of the saturated fatty acids. Meanwhile, they were weakly inversely correlated with the percentage of the sum polyunsaturated fatty acids and P:S ratio. In the obese diabetic rats, the above findings were met with but, they were more pronounced and in some instance they were more significant. The positive correlation of the atherogenic index with the P:S ratio can be explained by the fact that polyunsaturated fatty acids besides their hypocholesterolemic and hypotrigyceridemic effect they also depress HDL-C [37] which in case of the atherogenic index formula (HDL-C forms the donominator). These correlations findings are more or less the reverse to those found in human subjects in previous study published in 1999 by Osfor et al [38], but it should be remembered that in the rat most of the cholesterol in the plasma is carried with the HDL-C moiety [29]. Unlike in humans where cholesterol is mostly carried with LDL-C. This means that saturated fatty acids including C14:0 are more hypercholesterolemic than unsaturated.

In conclusion, although the results of experiments on rats cannot be exclusively exploited on human, however this work showed that dietetic substrates have got their impact on body metabolism, which undoubtedly adds to the genetic effect of predisposed individuals. In this regard, it seems appropriate to conduct some wider comparative study on rats which are genetically predisposed to dyslipidemias and on those which are not genetically predisposed to find out how diet and inheritance interplay.

\section{References}

[1] M. Croze, R. Vella, N. Pillon, H. Soula, L. Hadji, M. Guichardant, and C. Soulage, "Chronic treatment with myo-inositol reduces white adipose tissue accretion and improves insulin sensitivity in female mice", The Journal of Nutritional Biochemistry, 2013, 24(2): 457-466.

[2] T. Pischon, H. Boeing, and K. Hffmann, "General and abdominal adiposity and risk of death in Europe", N. Engl. J. Med. 2008, 359(20): 2105-2120.

[3] L. Storlien, A. Jenkkins, D. Chisholm, W. Pascoe, S. Khouri, and E. Kraegen, (1991): "Influence of dietary fat composition on development of insulin resistance in rats relationship to muscle triglycerides and n-3 fatty acids in muscles phospholipids", Diabetes, 40: 280-289.

[4] T. Pelinkanova, M. Kohout, J. Valek, J. Base, and L. Kazdova, "Insulin secretion and insulin action related to the serum phospholipids fatty acids pattern in healthy men", Metabolism, 1989, 38(2): 188-192.

[5] E. Berry, J. Hirsch, J. Most, D. McNamara, and J. Thornton, "The relationship of dietary fat to plasma lipid levels as studied by factor analysis of adipose tissue fatty acid composition in a free-living population of middle aged American men", Am. J. Clin. Nutr. 1986, 44: 220-231.

[6] J. Triscari, N. Koral, B. Levin, and A. Sullivan, "Changes in lipid metabolism in diet-induced obesity", Metabolism 1985, 34(6): 580-587.

[7] M. Osfor, "Protective role of green Tea and Panax ginseng in cancer-promoting Diets: a sub-chronic study on the male albino rats", Bull. NRC, Egypt, 2003, 28(5): 591 - 621.

[8] J. Folch, and G. Stanley, "A simple method for the isolation and purification of total lipids from animal tissue", J. boil. Chem. 1957, 226: 497.

[9] G. Siest, J. Henny, and F. Schiele, (1981): Interpretation des examens de Laboratorire. Karger ed. pp: 206-223.

[10] R. Yalow, and W. Bouman, Plasma Insulin in Health and Disease. In: Diabetes mellitus: Theory and Practice, M. Edinberg and H. Rifkin (Eds.), Excerpta Medica, New York, pp: 119-150, 1983.

[11] J. Schmit, and B. Drevon, "Sulfo-phospho-Vanillic reaction in lipid and lipoprotein evaluation in baboon serum comparison with human serum", Compt. Rend. Soc. Boil. 1964, 158(4), 778-780. 
[12] V. Dole, "Fractionation of plasma non- esterifies fatty acids Proc", Soc. Exptl. Biol. Med. 1956, 93: 532-533.

[13] P. Fossati, and L. Prencipe, "Serum triglycerides determined calorimetrically with an enzyme that produces hydrogen peroxide", Clin. Chem. 1982, 28: 2077.

[14] E. King, and I. Woolton, Microanalysis in Medical Biochemistry, 3rd ed. Churchill LTD: London, 1956.

[15] C. Allain, L. Poon, C. Chan, W. Richmond, and P. Fu, "Enzymatic determination of total cholesterol", J. Clin. Chem. $1974,20: 470-475$.

[16] C. Ratliff, and F. Hall, Laboratory Manual of Clinical Biochemistry. USA, Scott and White Memorial Hospital Publications Office Temple, IX, 1977.

[17] M. Lopez-Virella, P. Stoine, S. Ellis, and J. Acollwall, "Cholesterol determination in high density lipoprotein by three different methods", Clin. Chem. 1977, 53(5): 882-884.

[18] T. Glatter, "Hyperlipidemia, What is normal, who should be treated and how?", Post-Grad Med. 1984, 76(6): 49-59.

[19] P. Armitage, "Statistical Methods in Medical Research", 3rd ed. Blackwell scientific Publications, Oxford and Einburgh, England, 1974.

[20] C. Lavie, R. Milani, and H. Ventura, "Obesity and cardiovascular disease; risk factor, Paradox, and impact of weight loss", J. Am. Coll. Cardiol. 2009, 53: 1925-1932.

[21] S. Grundy, J. Cleeman, and R. Daniels, "Diagnosis and management of the metabolic syndrome, Circulation, 2005, 112: $2735-3752$.

[22] S. Grundy, B. Hansen, and Jr S. Smith, "American heart association; national heart, Lung and blood Institute; American diabetes association 2004 Clinical management of the metabolic syndrome: report of the American Heart association/ National heart, lund, and Blood institute/ American Diabetes association Conference on scientific issues related to management", Circulation, 2004, 109: 551-556.

[23] J. Baker, L. Olsen, and T. Soprensen, "Childhood body-mass index and the risk of coronary heart disease in adulthood", N. Engl. J. Med. 2007, 357: 2329-2337.

[24] A. Oreopoulos, R. Paswal, and K. Kalantar-zadeh, "Body mass index and mortality in heart failure: a meta analysis", Am. Heart J. 2008, 156: 13-22.

[25] L. Barness, J. Opitz, and E. Gilbert-Barness, "Obesity: genetic, molecular, and environmental aspects", Am. J. Med. Genet. 2007, 143A (24): 3016-34.

[26] T. Constantine, H. Vojtech, B. Arnaud, F. Nick, F. Martin, M. Elisabeth, M. Dragan, and M. Mximo, "Management of ob- esity in adults: European Clinical Practice Guidelines", The European Journal of Obesity, 2008, 1(2): 106-116.

[27] R. Ness-Abramof, and C. Apovian, "Diet modification for treatment and prevention of obesity", Endocrine, 2006, 29 (1): $5-9$.

[28] P. De Varies, H. Folkers, and C. Defijter, "Adipose tissue fatty acid composition and its relation to diet and plasma lipid concentrations in haemodialysis patients", Am. Clin. Nutr. 1991, 53:468-473.

[29] G. Whitlock, S. Lewington, and P. Sherliker, "Body mass index and cause specific mortality in 900000 adults: Collaborative analysis of 57 prospective studies", Lancet, 2009, 373: $1083-1096$.

[30] R. Brownson, T. Boehmer, and D. Luke, "Declining rates of physical activity in the united states: what are the contributors?", Annu Rev. public Health, 2005, 26: 421-443.

[31] K. Borodulin, T. Laatikainen, A. Juolevi, and P. Jousilahti, "Thirsty year trends of physical activity in relation to age, calendar time and birth cohort in finnish adults", Eur. J. Public Health, 2008, 18 (3): 339-344.

[32] M. Fried, V. Hainer, and A. Basdevnt, "Inter-disciplinary European guidelines on surgery of severs obesity", Int. J. Obes. (Lond), 2007, 31(4): 569-577.

[33] I. Cusin, F. Rohner-Jeanreenaud, J. Jenettaz, and B. Jeanrenaud, "Hyperinsulinemia and its impact on obesity and insulin resistance", Int. JK, 1992, Obesity 16 (4), SI-SII.

[34] W. Mckane, A. Stevers, R. Woods, W. Andrews, R. Henry, and P. Bell, "The assessment of hepatic and peripheral insulin sensitivity in htpertriglyceridemia", Metabolism, 1990, 39 (12), 1240-1245.

[35] R. Harris, and H. Kor, "Insulin insensitivity is rapidly reversed in rats by reucing dietary fat from 40 to $30 \%$ of energy", J Nutr. 1992, 122: 1811-1822.

[36] R. Krauss, M. Winston, B. Fletcher, and S. Graundy, "Obesity is not an independent risk factor for adverse peri-operative and long-term Clinical outcomes following Open AAA Repair or Evar VASC", Endovascular Surg. 2011, 45: 607-613.

[37] E. Schaefer, R. Levy, N. Renst, F. Van sant, and H. Brewer, "The effect of low cholesterol, high polyunsaturated fat, and low fat diet on plasma lipids and cholesterol levels in normal and hypercholesterolemic subjects", Am. J. Clin. Nutr. 1981, $34,1758-1763$.

[38] M. Osfor, W. Nicola, E. Badawy, and M. Emam, "Composition of plasma lipoproteins and their impact on metabolic complication in fatness rats treated with metformin and nicotinic acid", Med. J. Cairo Univ., 1999, 67(1) (suppl.) 59 73 . 